\title{
THE USE OF NATURAL SEPIOLITE FIBER IN CONCRETE
}

\section{UPORABA NARAVNEGA SEPIOLITNEGA VLAKNA V BETONU}

\author{
Selçuk Koltka ${ }^{1}$, Tayfun Uygunoğlu ${ }^{2}$, Eyüp Sabah ${ }^{1}$, Muhammed Fatih Can ${ }^{1}$ \\ ${ }^{1}$ Afyon Kocatepe University, Department of Mining Engineering, 03200 Afyonkarahisar, Turkey \\ ${ }^{2}$ Afyon Kocatepe University, Deparment of Civil Engineering, 03000 Afyonkarahisar, Turkey \\ uygunoglu@aku.edu.tr
}

Prejem rokopisa - received: 2015-07-08; sprejem za objavo - accepted for publication: 2015-12-23

doi:10.17222/mit.2015.210

\begin{abstract}
To determine the effect of sepiolitic fibers on the characteristics of fresh and hardened concrete, i.e., slumping, density, air content, ultrasonic pulse velocity, freeze-thaw, compressive strength, bending and splitting, tensile strength tests were conducted by the addition of de-fibered sepiolite to the cement in ratios of $0.5 \%, 1 \%, 2 \%$ and $3 \%$ of mass fractions. The fibers support higher slumping for fresh concrete and increased workability. Samples with $1 \%$ and $3 \%$ addition have similar compressive strength values to the reference series after $28 \mathrm{~d}$. The bending strength of the $2 \%$ added sample is closer to the bending strength of the 28-days reference concretes; however, it is reduced for $0.5 \%, 1 \%$ and $3 \%$. For all the reinforcement ratios the splitting strength increased. The highest impact strength performed for a $3 \%$ reinforcement sample increased by $29 \%$ and scanning electron microscopy (SEM) investigations reveal that the white sepiolite fibers are dispersed homogenously in the concrete, and therefore it, reinforce especially at the interface of the aggregate cement paste by increasing durability.

Keywords: sepiolite fiber, mechanical activation, fiber reinforced concrete.
\end{abstract}

Za določitev vpliva sepiolitnih vlaken na značilnosti svežega in strjenega betona so bili izvedeni; razlivanje pri padcu, gostota, vsebnost zraka, hitrost ultrazvočnega impulza, zmrznjenje in odtajanje, tlačna trdnost, upogibanje in cepilno natezna trdnost $z$ dodatkom razvlaknjenega sepiolita betonu v masnih deležih $0,5 \%, 1 \%, 2 \%$ in $3 \%$. Vlakna pospešujejo razlivanje svežega betona in izboljšajo njegovo oblikovalnost. Vzorca z dodatkom $1 \%$ in $3 \%$ sta pokazala podobno tlačno trdnost kot referenčna serija po 28 d. Upogibna trdnost pri vzorcu z $2 \%$ dodatka je zelo blizu upogibni trdnosti referenčnega betona po 28 d; vendar je manjša pri dodatkih $0,5 \%, 1 \%$ in $3 \%$. Pri vseh dodatkih pa je cepilna trdnost narasla. Najvišja udarna žilavost izvedena pri vzorcu s $3 \%$ dodatkom je narasla za $29 \%$ in preiskava z vrstičnim elektronskim mikroskopom (SEM) je odkrila, da so bela sepiolitna vlakna homogeno razpršena $\mathrm{v}$ betonu, zato ojačajo stik agregata s cementno pasto in povečajo trajnost betona.

Ključne besede: sepiolitna vlakna, mehanska aktivacija, z vlaknom ojačan beton

\section{INTRODUCTION}

The term fiber reinforced concrete (FRC) is defined by the American Concrete Institute (ACI) Committee $544^{1}$ as a concrete made of hydraulic cements containing fine or fine and coarse aggregates and discontinuous discrete fibers. Inherently, concrete is brittle under tensile loading. The mechanical properties of concrete can be improved by reinforcement with randomly oriented short discrete fibers, which prevent and control the initiation, propagation, or coalescence of cracks. ${ }^{2,3}$ The character and performance of FRC changes depending on the matrix properties as well as the fiber material, fiber concentration, fiber geometry, fiber orientation, and fiber distribution. ${ }^{4,5}$

In the construction industry, which has undergone a very rapid development period since the 1980s, fiber-reinforced precast concrete products have been fulfilling an important role for both designers and contractors by offering technical and aesthetic convenience. Because of the health problems it caused, asbestos, once widely used as a provider of fibrous structure, left its place to fibrous synthetic materials. ${ }^{6}$ Straw was used to reinforce sun-baked bricks, and horsehair was used to reinforce masonry mortar and plaster. Human beings have always been remarkably adaptable, working with the materials around them to make whatever is required. A wide variety of fibers have thus been used with cement-based matrices. They include metallic fibers, polymeric fibers, mineral fibers and vegetable fibers. In recent years, a great deal of interest has been created worldwide in the potential applications of natural fiber-reinforced, cement-based composites ${ }^{7,8}$. Wood, grasses, clay and stone have all been used as they occur naturally, but man's ability to process natural resources has improved in parallel with man's own development. In modern times, a wide range of engineering materials (including ceramics, plastics, cement, and gypsum products) incorporate fibers to enhance the composite properties. ${ }^{1,9}$ F. O. Slate ${ }^{10}$ investigated the compressive and flexural strength of coconut-fiber-reinforced mortar. Two cement-sand ratios by weight, 1:2.75 with a water cement ratio of 0.54 and 1:4 with a water cement ratio of 0.82 were considered. The fibre content was $0.08 \%$, $0.16 \%$ and $0.32 \%$ by total weight of cement, sand and water. The mortar specimens were cured for $8 \mathrm{~d}$ only. It was found that, compared to that of plain mortar of both mix designs, all the strengths were increased in the case of fiber-reinforced mortar with all the considered fiber contents. However, a decrease in the strength of the 
mortar with an increase of the fiber content was also observed. Z. Li et al. ${ }^{11}$ studied the fiber-volume fraction and the fiber-surface treatment with a wetting agent for coir-mesh-reinforced mortar using non-woven coir mesh matting. They performed a four-point bending test and concluded that cementitious composites, reinforced by three layers of coir mesh with a low fiber content of $1.8 \%$, resulted in a $40 \%$ improvement in the maximum flexural strength. The composites were 25 times stronger in flexural toughness and about 20 times higher in flexural ductility when compared to plain composites. R. Siddique $^{12}$ used the natural san fibers (its botanical name is Crotalaria juncea) having a length of $25 \mathrm{~mm}$ and three percentages by volume of concrete $(0.25 \%, 0.50 \%$ and $0.75 \%)$ in concrete. The author investigated the fresh and hardened concrete properties such as slump, Vebe time, compressive strength, splitting tensile strength, flexural strength and impact strength. As result, it was found that the slump flow and compressive strength decreased with an increase in the percentage of san fibers when the flexural and impact strengths increased. However, some fibers can negatively affect the mechanical properties of composites. For example, the addition of sisal fibers to cement mortar matrices reduced the compressive strength by $18.4 \%$ to $32 \%$, the elastic modulus by $1.3 \%$ to $15 \%$, the longitudinal strain capacity at ultimate stress by $15.2 \%$ to $32.9 \%$, and the lateral strain capacity by $4.2 \%$ to $24.9 \%$. S. K. Al-Oraimi and A. C. Seibi $^{13}$ compared to natural and glass-fiber-reinforced concrete properties. They also report that strength is generally marginally decreased by the addition of glass and natural fibres. New types of fibers, new methods of fabrication and different types of applications are continuously being developed. One of them is sepiolite. ${ }^{8}$

Sepiolite is a natural clay mineral with a formula of magnesium hydrosilicate $\mathrm{Si}_{12} \mathrm{Mg}_{8} \mathrm{O}_{30}(\mathrm{OH})_{6}\left(\mathrm{OH}_{2}\right)_{4} \cdot 8 \mathrm{H}_{2} \mathrm{O}$ characterized by its fibrous morphology and intra-crystalline channels, extending in the fiber direction (c-axis). ${ }^{14}$ It has a fibrous structure formed by the alternation of blocks and channels that grow in the fiber direction. Each structural block is composed of two inverted tetrahedral silica sheets and a central octahedral sheet containing $\mathrm{Mg}$. In the inner blocks, all the corners of the silica tetrahedral are connected to adjacent blocks, but in the outer blocks, some of the corners are Si atoms bound to hydroxyls ( $\mathrm{Si}-\mathrm{OH}) .{ }^{15}$ This unique structure imparts sepiolite with a fibrous matrix with channels $\left(3.6 \times 10^{5} \mathrm{~nm}\right)$ oriented in the longitudinal direction of the fibers. The fibrous structure of sepiolite induces sorptive, colloidal/rheological and catalytic properties, which find a variety of diverse applications. The fiber length, width and thickness of layered sepiolite as bundles of fiber can range between $10 \mathrm{~nm}$ and $5 \mu \mathrm{m}$, between 10 and $30 \mathrm{~nm}$ and between 5 and $10 \mathrm{~nm}$, respectively. However, the length of the fibers in sepiolite varies according to the source of sepiolite. ${ }^{16}$ For example, the length of Ampandrandawa and China sepiolites reaches up to a few milli- meters, and sometimes even a centimeter. While the fiber dimensions of Vallecas (Spain) sepiolite are $800 \mathrm{~nm} \times$ $25 \mathrm{~nm} \times 4 \mathrm{~nm},{ }^{17}$ the fiber length of the original brown sepiolite from the Türktaciri region of Turkey is determined as $5-10 \mu \mathrm{m} .{ }^{18}$

The sepiolite was used in the production of cement as natural clay (raw material) by Kavas et al. ${ }^{6}$ Sepiolite was replaced with clinker in proportions of $(3,5,10,15,20$ and 30) \% by weight. Mortar specimens were prepared with sepiolite-blended cement at a water to cement ratio of 0.5 . The addition of $10 \%$ sepiolite is found to increase both the compressive and bending strengths of the mortar. However, there is very limited study in the literature on the performance of sepiolite as fiber in concrete. Therefore, in this study, it was decided to use sepiolite fibers in order to prevent micro-cracks occurring in the concrete matrix under load so that it improve the physico-mechanical properties of concrete, such as compressive, bending, and splitting strengths.

\section{EXPERIMENTAL PART}

\subsection{Materials}

\subsubsection{Aggregate}

The maximum $22 \mathrm{~mm}$ nominal size of crushed aggregate from Afyonkarahisar, Turkey was used. The coarse aggregates were calcareous stone as crushed stone I in $4-11 \mathrm{~mm}$; and crushed stone II in 11-22 $\mathrm{mm}$. The fine aggregates were crushed stone dusty in $0-4 \mathrm{~mm}$. The characteristic properties of the aggregates are given in Table $\mathbf{1}$ according to standards.

Table 1: Aggregate properties

Tabela 1: Lastnosti agregata

\begin{tabular}{|c|c|c|c|c|c|}
\hline $\begin{array}{c}\text { Particle } \\
\text { size } \\
(\mathrm{mm})\end{array}$ & $\begin{array}{c}\text { Specific } \\
\text { gravity } \\
\left(\mathrm{Mg} / \mathrm{m}^{3}\right)\end{array}$ & $\begin{array}{c}\text { Water } \\
\text { adsorp- } \\
\text { tion }(\%)\end{array}$ & $\begin{array}{c}\text { Particle } \\
\text { shape } \\
(\%)\end{array}$ & $\begin{array}{c}\text { Los } \\
\text { Angeles } \\
(\%)\end{array}$ & $\begin{array}{c}\text { Ultra fine } \\
\text { material }\end{array}$ \\
\hline $22.4-11.2$ & 2.69 & 0.13 & 13.4 & 30 & 0.56 \\
\hline $11.2-4$ & 2.69 & 0.28 & 14.7 & & 0.31 \\
\hline $4-0$ & 2.69 & 0.93 & & & 5.58 \\
\hline
\end{tabular}

\subsubsection{Cement}

Ordinary Portland cement (OPC) was used in the experiments with a minimum strength of $45 \mathrm{MPa}$ at $28 \mathrm{~d}$ (CEM I 42.5 R). It complies with the requirement of European Standards EN 197-1. ${ }^{19}$ The characteristic properties of cement are given in Table 2.

\subsubsection{Sepiolite}

The dolomitic sepiolite samples taken from the Eskisehir-Sivrihisar Region (purity grade is $40 \%$ ) are subject to reinforcement procedure, and the sepiolite samples with fibers uncoupled by a mechanical activation (Figure 1) are used in the manufacture of the fiber-reinforced concrete. After the dolomitic sepiolite having a $10,000 \mathrm{mPa} \cdot \mathrm{s}$ times $10 \%$ (poor quality) is reinforced by gravitational methods, its viscosity increases 
Table 2: Characteristic properties of CEM I 42.5R cement Tabela 2: Značilne lastnosti cementa CEM I 42,5R

\begin{tabular}{|c|c|}
\hline Component & Content, \% \\
\hline $\mathrm{CaO}$ & 63.56 \\
\hline $\mathrm{SiO}_{2}$ & 19.3 \\
\hline $\mathrm{Al}_{2} \mathrm{O}_{3}$ & 5.50 \\
\hline $\mathrm{Fe}_{2} \mathrm{O}_{3}$ & 3.46 \\
\hline $\mathrm{MgO}$ & 0.86 \\
\hline $\mathrm{SO}_{3} \mathrm{~K} \mathrm{Ka}_{2} \mathrm{O}$ & 2.96 \\
\hline $\mathrm{Na}_{2} \mathrm{O}$. & 0.80 \\
\hline \multicolumn{2}{|c|}{ Physical properties } \\
\hline \multicolumn{2}{|c|}{0.13} \\
\hline Initial setting time, h & 1.15 \\
\hline Final setting time, h & 2.52 \\
\hline Volume expansion, mm & 4.36 \\
\hline Blaine surface area, cm $/ \mathrm{g}$ & 3.00 \\
\hline Specific weight, g/cm & 3212 \\
\hline \multicolumn{2}{|c|}{$\mathrm{Mechanical}$ properties } \\
\hline Compressive strength, MPa & $7 \mathrm{~d}$ \\
\hline \multicolumn{2}{|c|}{3.07} \\
\hline
\end{tabular}

up to $19,000 \mathrm{mPa} \cdot \mathrm{s}$. The sepiolite to be used as a fiber in a concrete is a reinforced white sepiolite having uncoupled fibers and a viscosity of $19,000 \mathrm{mPa} \cdot \mathrm{s}$. A blender was used to disperse the fiber bundles that form the structure of the sepiolite and provide the gelation at

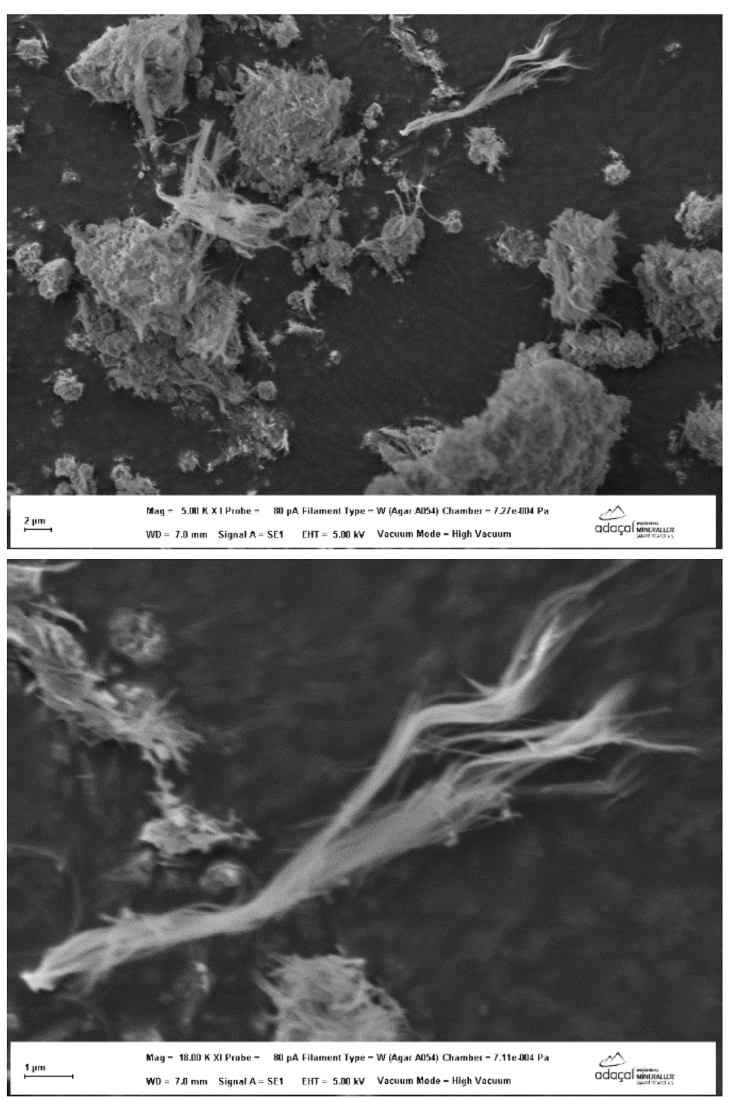

Figure 1: SEM images of sepiolite fibers Slika 1: SEM-posnetka sepiolitnih vlaken high speed $\left(\max 20,000 \mathrm{~min}^{-1}\right)$. Sepiolite suspensions prepared in the $2000 \mathrm{~mL}$ steel cup of a blender.

\subsubsection{Superplasticizer}

A polycarboxylic-based new generation superplasticizer admixture was used to obtain a good workability for the fresh SEPRC mixture. Its specific gravity was $1.2 \mathrm{~kg} / \mathrm{dm}^{3}$.

\subsection{Preparation of SEPRC specimens}

Several series of samples were prepared to test the influential variables on the mechanical and physical properties of fresh and hardened concretes with sepiolite. The cement dosage, water to cement ratio and chemical admixture content were $350 \mathrm{~kg} / \mathrm{m}^{3}, 0.55 \%$ and $1.5 \%$ (by weight of cement), respectively, in the mixtures. The volume of aggregate was determined for the reference Portland cement concrete by assuming that approximately $1.5 \%$ of air is trapped in the fresh concrete. The sixteen different series were designed by using fiber contents as $0 \%$ (control), $0.5 \%, 1 \%, 2 \%$ and $3 \%$ by weight of cement. The mixing of concrete batches was carried out using a small drum mixer. The concrete dried components were mixed for $2 \mathrm{~min}$. Then, to encourage a uniform distribution of fibers throughout of the concrete, fibers were added to the mixing water slowly (with diluted admixture). The mixing water was poured into a drum; the aggregates and cement were fully mixed. The fresh concrete was mixed for 3 min (Figure 2). The mixture proportion per cubic meter of sepiolite-fiber-rein-

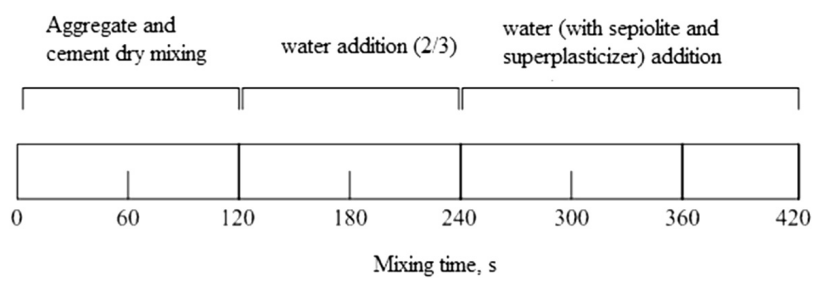

Figure 2: Concrete mixing procedure depends on the time Slika 2: Mešanje betona je odvisno od časa

Table 3: Physico-mechanical tests on SEPRC

Tabela 3: Fizikalno-mehanski preizkusi na SEPRC

\begin{tabular}{|c|c|c|}
\hline Experiments & Specimen Size & Standard \\
\hline \multicolumn{3}{|c|}{ Fresh concrete } \\
\hline Slump test ${ }^{20}$ & $6 \mathrm{dm}^{3}$ & EN 206-1 (2000) \\
\hline Unit weight $^{21}$ & $7 \mathrm{dm}^{3}$ & EN 12350-6 (2009) \\
\hline Air content ${ }^{22}$ & $7 \mathrm{dm}^{3}$ & EN 12350-7 (2009) \\
\hline \multicolumn{3}{|c|}{ Hardened concrete } \\
\hline $\begin{array}{l}\text { Compressive } \\
\text { strength }^{23}\end{array}$ & $(150 \times 150 \times 150) \mathrm{mm}$ & EN 12390-3 (2009) \\
\hline Splitting strength ${ }^{24}$ & $(\varnothing 150 \times 300) \mathrm{mm}$ & EN 12390-6 (2009) \\
\hline Flexural strength ${ }^{25}$ & $(100 \times 100 \times 350) \mathrm{mm}$ & EN 12390-5 (2009) \\
\hline $\begin{array}{l}\text { Ultrasonic pulse } \\
\text { velocity }^{26}\end{array}$ & $(150 \times 150 \times 150) \mathrm{mm}$ & EN 13791 (2007) \\
\hline $\begin{array}{l}\text { Freezing-thawing } \\
\text { test }^{27}\end{array}$ & $(100 \times 100 \times 150) \mathrm{mm}$ & EN 1367-1 (2007) \\
\hline
\end{tabular}


forced concrete (SEPRC) is given in Table 2. The fresh concrete was placed in the moulds with a shaker and they were de-molded after $24 \mathrm{~h}$. The specimens were cured in water at $20^{\circ} \mathrm{C}$ for $7 \mathrm{~d}$ and $28 \mathrm{~d}$. The experiments that are carried out on the SEPRC series are summarized in Table 3 according to the related standard. ${ }^{21-28}$

For the SEPRC specimens, compressive strength was defined according to the EN 12390-323 standard using a $2000 \mathrm{kN}$ compressive machine with a rate of loading controller on cubic specimens (Table 4) aged for $7 \mathrm{~d}$ and $28 \mathrm{~d}$, respectively. Flexural strength was defined on the prismatic specimens under the mid-point loading with $200 \mathrm{kN}$ manual controlling bending test machine. For the freeze-thaw testing, the SEPRCs were exposed to ASTM C666 ${ }^{28}$ Procedure A conditions: the specimens were kept in a fully saturated condition with temperature cycling between $-17{ }^{\circ} \mathrm{C}$ and $+20{ }^{\circ} \mathrm{C}$, each cycle took $6 \mathrm{~h}$. The climatic chamber used consisted of cooling and heating equipment producing continuous freeze-thaw cycles with chamber temperatures ranging from $-20{ }^{\circ} \mathrm{C}$ to +20 ${ }^{\circ} \mathrm{C}$. The specimens were frozen for $1 \mathrm{~h}$ in air at $-17{ }^{\circ} \mathrm{C}$, and then they were immersed into the water to thaw for 2 $\mathrm{h}$ at $+20{ }^{\circ} \mathrm{C}$. In total, 30 freeze-thaw cycles were performed on each of the SEPRCs.

Table 4: Quality of concrete with ultrasonic testing ${ }^{29}$ Tabela 4: Ocena kvalitete betona $\mathrm{z}$ ultrazvočnim preizkušanjem ${ }^{29}$

\begin{tabular}{|c|c|}
\hline Wave velocity $(\mathrm{km} / \mathrm{s})$ & Quality of concrete \\
\hline$>4.5$ & Perfect \\
\hline $3.5-4.5$ & Best \\
\hline $3.0-3.5$ & Suspect \\
\hline $2.0-3.0$ & Weak \\
\hline$<2.0$ & Very weak \\
\hline
\end{tabular}

Moreover, freshly fractured surfaces of the SEPRC chips were coated with gold in a vacuum evaporator. They were examined using a Zeiss EVO LS 10 scanning electron microscope (SEM) to determine the morphological and mineralogical features.

\section{RESULTS AND DISCUSSIONS}

\subsection{Fresh concrete tests}

The slump test that makes it possible to determine the inspection of viscosity of the fresh concrete easily and properly is the slump test. The slump value of $0.5 \%$, $1 \%, 2 \%$ and $3 \%$ of the SEPRC are 17, 16.3, 17 and 6 respectively, while the slump value of the reference concrete ( $0 \%$ sepiolite) is 16 . In $3 \%$ SEPRC fiber-reinforced concrete, critical reason of a reduction in the slump value is that the sepiolite fibers have large surface areas and a capability to retain water particles ${ }^{29}$. Thus, the concrete containing $3 \%$ sepiolite has almost no consistency because of high viscosity and becomes unworkable. However, it is behind the limits specified in the EN 206-120 standard for slump values. In lower sepiolite reinforcement ratios, the slump values are within acceptable limits for concrete manufacture. For instance, $0.5 \%, 1 \%$ and $2 \%$ sepiolite-reinforced concretes are $\mathrm{S} 3$ grade, while the inspection series are $\mathrm{S} 4$ grade, in accordance with the EN 206-120 standard for slump values. In the SEPRC, workability of the concretes increases up to a fiber use at $2 \%$ and their slump values increase by approximately $6 \%$ with respect to the inspection series. But, as the fiber amount increases more, the slump value decreases significantly. The inspection series and SEPRCs up to a $2 \%$ fiber addition are S4 grade, in accordance with the EN 206-120 standard for slump values, and the final series are S1 grade.

In Figure 3 it is clear that because slump value of SEPRC $0.5 \%$ and SEPRC $2 \%$ is $17 \mathrm{~cm}$, while slump value of the reference concrete $16 \mathrm{~cm}$, workability of the concrete is much better than SEPRC 0. In other words, sepiolite fibers increase the workability of plain concrete. R. Jarabo et al. ${ }^{30}$ also reported that sepiolite modifies the rheological properties of cement when used as an additive. This is an important result, because almost all the fiber types that were used to improve the mechanical properties, generally reduced the workability. However, $3 \%$ fiber added to the concrete absorbs water and cement and creates a powerful mesh structure. Therefore, an increase in viscosity restricts the flow and gives a lower slump value $(6 \mathrm{~cm})^{31,32}$. Thus, J. Edgington et al. ${ }^{33}$ recommend a $2 \%$ steel fiber content maximum and show that as polypropylene fibers are added more than $1 \%$, they cause a large decrease in workability. In this study, it is determined that a $3 \%$ fiber addition reduces the workability.

A gap remains absolutely in fresh concrete during the pouring of concretes in molds. Concretes are compressed and placed by vibration or other methods in their molds and thus such gaps are minimized. Gaps trapped in the concrete both reduce the strength of the concrete and cause the concrete to contain more gaps, and thus to become more instable against any exterior environmental effects while the concrete is hardened. Figure 3 shows the air content in the white sepiolitic fiber-reinforced concrete. Except in particular circumstances (such as concretes subject to freeze-thaw), it is not assumed that a fresh concrete contains a gap between $2-3 \%$ and a hard-

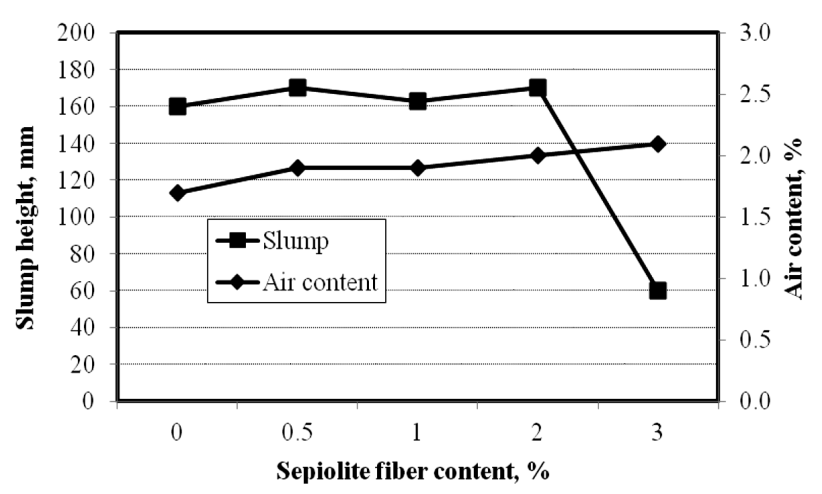

Figure 3: Slump and air content of sepiolite-reinforced concrete Slika 3: Razlezenje in vsebnost zraka v betonu ojačanem s sepiolitom 


\section{S. KOLTKA et al.: THE USE OF NATURAL SEPIOLITE FIBER IN CONCRETE}

ened concrete contains a gap more than 6-8 \%. It can be seen that the air content of SEPRC fibers is between $1.5 \%$ and $2.1 \%$. Therefore, air content of the concretes containing SEPRC is within the proposed range.

Unit weights of fresh SEPRCs are presented in Figure 4. There is no change in the unit weight values of fresh concrete depending on an increase in sepiolite ratios added to concrete and such values of around $2360-2400 \mathrm{~kg} / \mathrm{m}^{3}$.

\subsection{Hardened concrete}

\subsubsection{Compressive strength}

The cube samples manufactured in the sepiolite-reinforced concretes are subject to the compressive strength. 7- and 28-day strengths are determined for the time-dependent strength of the samples. The age of the samples in all concrete series gets along, depending on the strength development and thus their compressive strength increases depending on the development of any hydration products. While their compressive strength reduces by $5 \%$ when the sepiolite fibers are used at $0.5 \%$, as shown in Figure 5, their strength remains the same as the reference series, when they are at $1 \%$ and $3 \%$ at 28 d. The probable reason for this behavior includes poor zones occurring due to poor homogeneity of the concrete, a high water ratio or an excessive amount of fibers. Similar results were observed on natural coconut-fiber-reinforced concrete by M. Ali et al. ${ }^{34}$. The mechanical properties such as the static modulus of elasticity, compressive strength, compressive toughness, splitting tensile strength, modulus of rupture, total toughness index and density were investigated by the authors. They reported that the properties can increase or decrease depending on fiber length and content.

\subsubsection{Flexural strength}

In concrete series containing SEPRC, the results that are closest to the reference series are obtained in the concretes containing $1 \%$ SEPRC. Upon the addition of $3 \%$ fiber, the bending strength values are increased by approximately $22.9 \%$ (Figure 6). However, it is deter-

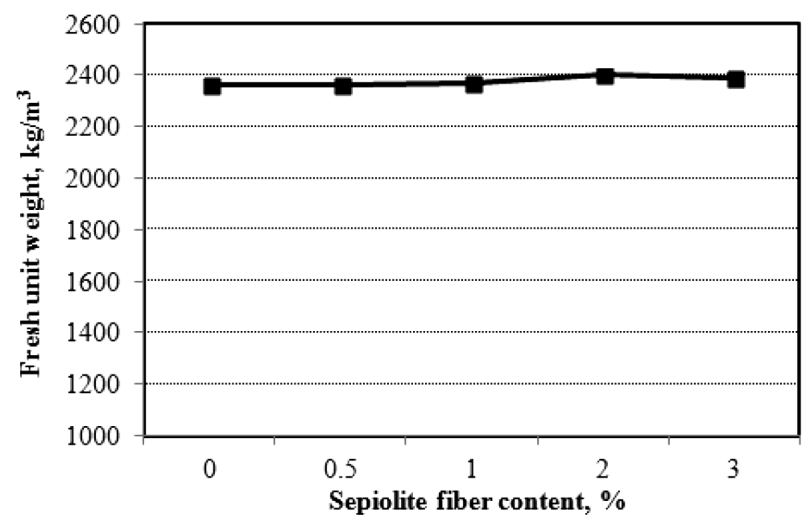

Figure 4: Fresh unit weight of sepiolite fiber-reinforced concrete Slika 4: Enota sveže mase betona ojačanega s sepiolitnimi vlakni

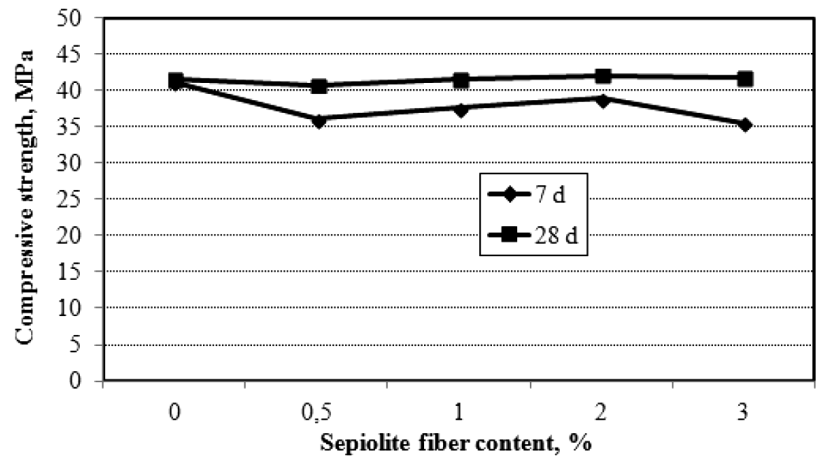

Figure 5: Compressive strength of SEP-reinforced concrete Slika 5: Tlačna trdnost betona utrjenega s SEP

mined that the bending strength of the concretes was reduced due to difficulties in mixture and molding of the $3 \%$ sepiolitic fiber-reinforced concrete when compared to $2 \%$ of fiber content. It is reported by M. Emiroğlu ${ }^{35}$ that, upon addition of sepiolite to the concrete, it reduces the workability and there is a reduction in the bending and compressive strengths due to its ability to retain an excessive amount of water. It is determined that a large number of micro acicular sepiolite fibers are dispersed between the matrix and the aggregates, while the sepiolitic fiber addition is $2 \%$. An increase in workability of the SEPRC concretes confirms the homogeneity in the microstructure. Its effects on rupture behavior are clearer than an increase in the bending strengths of the sepiolitic fibers.

\subsubsection{Splitting strength}

The weakest properties of the structural materials such as cement-based concrete include a lower tensile strength. Therefore, a different type and nature of fibers are added to the concrete to increase or improve its tensile strength. One of the tests, where the tensile strength is determined, is the splitting strength that gives the tensile strength indirectly in a real-like way. Aggregate dispersion of the SEPRC3 sample in the concrete that gives a high splitting strength is homogenous. Furthermore, the concrete is not separated from its matrix, but it is ruptured and broken into two parts during the force applied in the splitting of the concrete. The reason for this

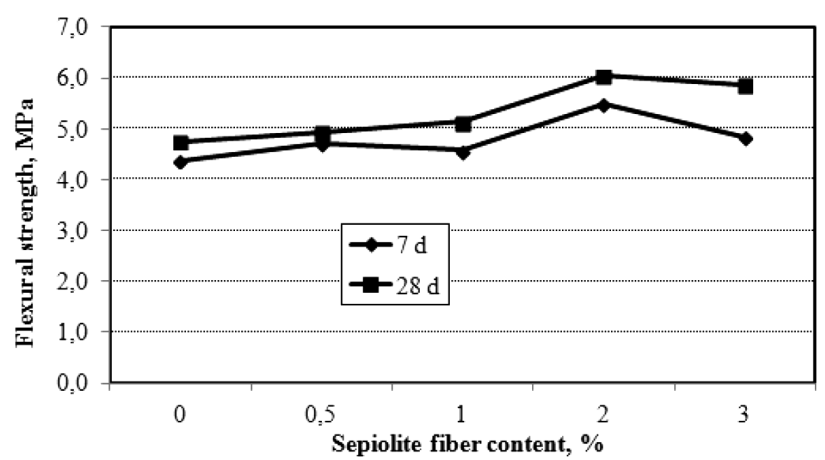

Figure 6: Flexural strength of SEP-reinforced concrete Slika 6: Upogibna trdnost betona utrjenega s SEP 
S. KOLTKA et al.: THE USE OF NATURAL SEPIOLITE FIBER IN CONCRETE

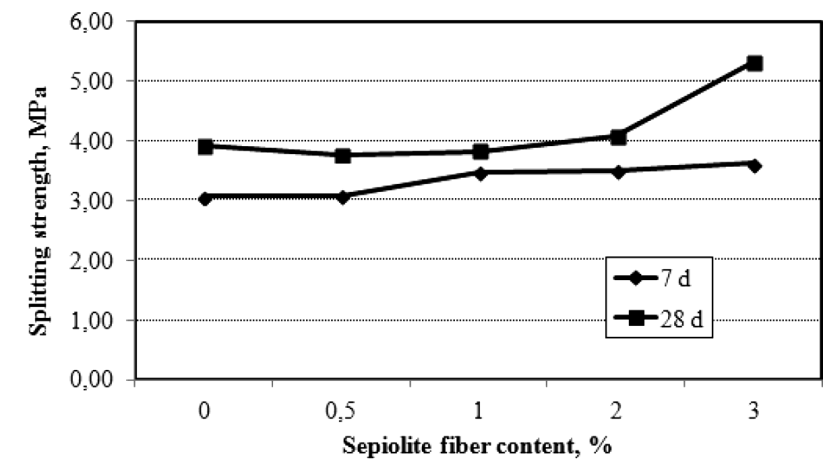

Figure 7: Splitting strength of SEP-reinforced concrete versus fiber content

Slika 7: Cepilna trdnost betona ojačanega s SEP glede na vsebnost vlaken

is that the matrix and the interface of the aggregate and matrix are reinforced by the sepiolite fibers. In the concrete samples that give a low splitting strength, the aggregate is ruptured and separated from the cement paste due to the poor interface of the cement paste and aggregate. ${ }^{36}$ It was observed that the sepiolitic fibers increase the adherence of the aggregate and cement paste and the splitting strength of the concrete (Figure 7). In the samples containing SEPRC, their splitting tensile strength increases by $6 \%$ and $33 \%$, respectively, upon the addition of $2 \%$ and $3 \%$ fiber, while their tensile strength never changes significantly upon the addition of $0.5 \%$ and $1 \%$ fiber.

\subsubsection{Microstructure}

In Figure 8a to $\mathbf{8 e}$, it was seen in the concrete sample that the hydrate cement matrix and the aggregate inter- face have a fairly dense structure. When a crack in this aggregate is observed by $20000 \times$ magnification, an anti-crack effect of the sepiolitic fibers (A) is observed clearly. Upon an increase of the sepiolitic fibers, it contributes positively for the cement paste to become more stable and the gaps in the concrete to reduce. The dense calcium hydroxide hydrate $(\mathrm{C}-\mathrm{S}-\mathrm{H})$ gels in the concrete and micro sepiolite fibers between these gels makes it possible to reduce the gap and to make the concrete denser. Figure 8, A, B and C show calcium hydroxide $(\mathrm{CH}), \mathrm{C}-\mathrm{S}-\mathrm{H}$ gel and the ettringite needles, respectively. Since it is a binder final product in a concrete, the $\mathrm{C}-\mathrm{S}-\mathrm{H}$ gel is a critical component, and consequently it contributes mostly to the strength. It is clear that strength development is fairly fast in the inspection series. It is very effective for any chemical additive used on these dispersed cement particles and react better with water. S. Kakooei et al. ${ }^{37}$ show that the macro fibers $(L=4 \mathrm{~mm})$ reduce the crack formation and development and increase the compressive strength. But, a large majority of studies conducted on polypropylene-reinforced concretes show that there is no or very little compressive strength. ${ }^{31,38}$ When the SEM image of the SEPRC0.5 concrete is analyzed in Figure 7, the nano-sepiolite fibers contribute the adherence of the interfaces of the aggregates. Also, the nano-fibers in the surface of the even aggregates improve the weakness in interface of the aggregate cement paste. In concretes, the interfaces of the aggregate cement paste have a critical effect on the mechanical properties of the concrete as much as the component features. ${ }^{39}$

It is determined that there is a film layer formed by calcium hydroxide on the aggregate surface in contact
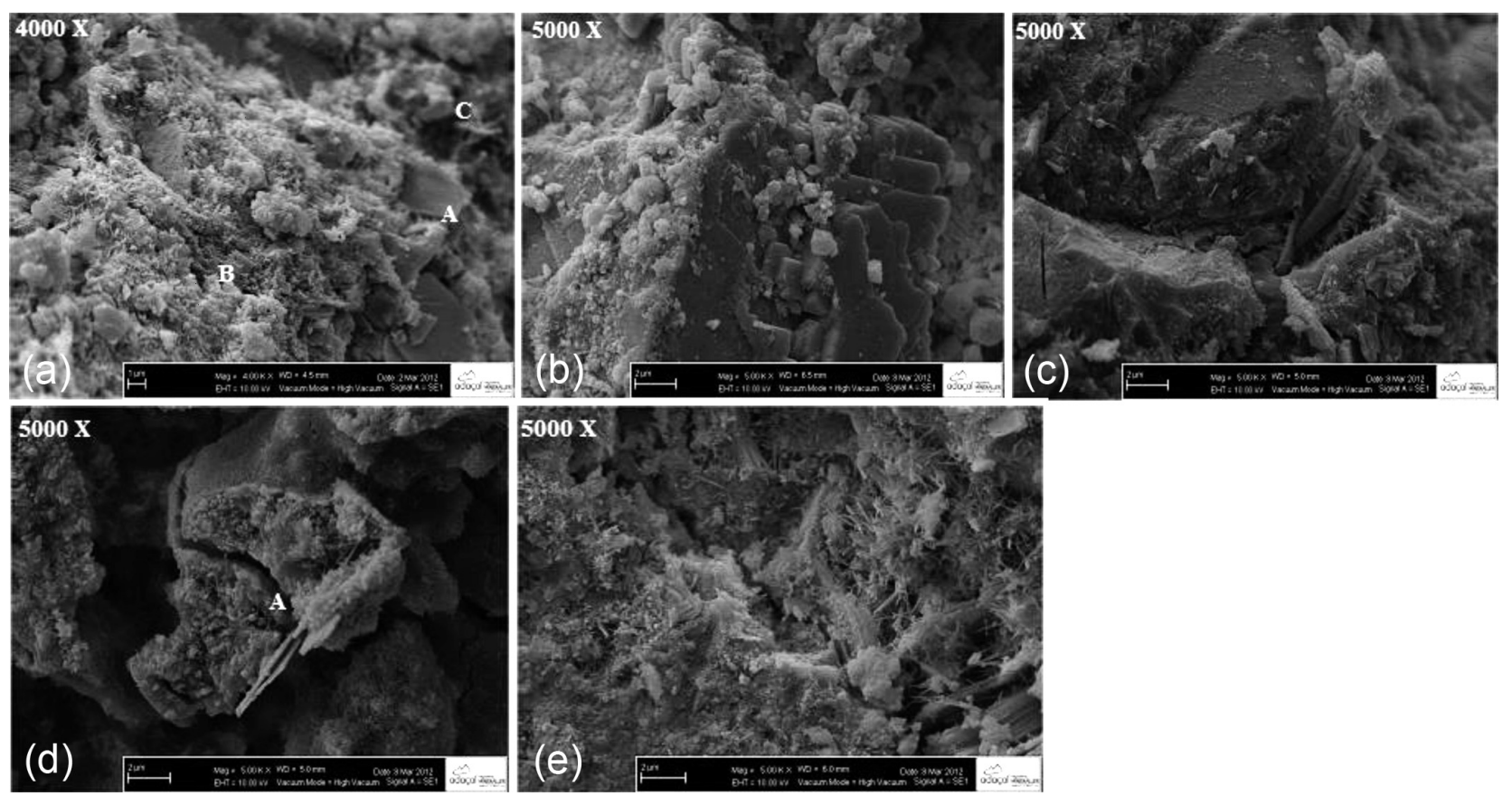

Figure 8: Distribution of sepiolite fibers in hydrated concrete: a) $0 \%$, b) $0.5 \%$, c) $1 \%$, d) $2 \%$, e) $3 \%$ ) Slika 8: Razporeditev vlaken sepiolita v hidriranem betonu: a) $0 \%$, b) $0.5 \%$, c) $1 \%$, d) $2 \%$, e) $3 \%$ ) 
with the transition zone and such a film is coated by another layer in a thin C-S-H (tobermorite) form. It is observed that such a double coat of film layer is also coated by a calcium hydroxide later in its interface..$^{40}$

\subsubsection{Ultrasonic pulse velocity}

Although it is difficult to find the compressive strength of any concrete by the ultrasonic test method in a sufficiently accurate way, because the ultrasonic wave velocity passing through any concrete is associated closely with amount (and density) of the gap in that concrete, it may be possible to establish a relation based on the resultant ultrasonic velocity and concrete grade. If the ultrasonic velocity is determined as a result of the experimental studies conducted on the concrete with a density of $2400 \mathrm{~kg} / \mathrm{m}^{3}$, the results on the concrete grade are shown in Table $4 .^{41}$ When the inspection series are compared in terms of ultrasonic pulse velocities in Figure 9, the ultrasonic velocity is obtained as $3.9 \mathrm{~km} / \mathrm{s}$, $4.3 \mathrm{~km} / \mathrm{s}, 4.5 \mathrm{~km} / \mathrm{s}$ and $4.4 \mathrm{~km} / \mathrm{s}$ for the $0.5 \%, 1 \%, 2 \%$ and $3 \%$ fiber contents in 28-day concretes. Since their ultrasonic pulse velocity is very close to $4.5 \mathrm{~km} / \mathrm{s}$, the concretes are in good and high-quality concrete grade. The concrete series with $0.5 \%$ fiber content are in a good concrete grade. It is recommended that fibers are used at a ratio of $2 \%$ and more for high-quality concrete manufacture in terms of ultrasonic pulse velocity.

\subsubsection{Modulus of elasticity}

The modulus of elasticity of concrete is a key factor for estimating the stiffness and deformation of the buildings and members. The precise determination of the modulus of elasticity of concrete is very important for structures that require strict control of the deformability. In order to make full use of the compressive strength potential, the structures using high-strength concrete tend to be slimmer and require a higher elastic modulus so as to maintain its stiffness. Therefore, knowledge of the modulus of elasticity of high-strength concrete is very important in avoiding excessive deformation, providing satisfactory serviceability, and avoiding the most cost-effective designs. ${ }^{42,43}$ In the codes and standards related to the design of concrete structures, the modulus of elasticity of concrete is usually proposed by empirical equations depending on a function of the compressive strength of the concrete. Therefore, the E-moduli values were obtained with ACI codes and Turkish standards (TS) depending on the compressive strength, and it was observed that they are relatively similar when comparing them with the recommendations found in ACI $318^{44}$, ACI $363^{45}$ and TS 500. The following equations are recommended by ACI $318^{36}$ and TS $500^{46}$ for the relationships between compressive strength $\left(f_{\mathrm{c}}\right)$ and the E-moduli is as follows for concretes:

$$
\begin{array}{lc}
(\text { ACI } 318)^{44} & E_{c}=4730 \times\left(f_{c}\right)^{1 / 2} \\
(\text { ACI } 363)^{45} & E_{c}=\left(\frac{g}{2.346}\right)^{1.5}\left(10500 \sqrt{f_{c}}+70000\right)
\end{array}
$$

$(\mathrm{TS} \mathrm{500})^{46} \quad E_{c}=14000+3250 \times\left(f_{\mathrm{c}}\right)^{1 / 2}$

Where $f_{c}, E_{c}$, and $\gamma$ represent the compressive strength $(\mathrm{mPa})$ elastic modulus of concrete $(\mathrm{mPa})$, and unit weight $\left(\mathrm{kg} / \mathrm{dm}^{3}\right)$ of sepiolite reinforced fiber concrete, respectively.

A comparison of static modulus of elasticity obtained from the empirical expressions given by the various design codes for both plain concrete and sepiolite fiber reinforced concrete is presented in Figure 10. It shows the modulus of elasticity predicted by TS $500^{46}$ is higher than compare to other code prediction. Values of elasticity modulus vary from 28 to $27 \mathrm{GPa}$ for ACI codes when it was $33 \mathrm{GPa}$ according to the TS $500^{46}$ standard. A slight decrease in the results is observed for ACI codes with an increasing addition of sepiolite volume fraction. However, there was no change for the power function of the TS $500^{46}$ standard. The modulus of elasticity of the concrete depends upon the modulus of elasticity of the hydrated cement matrix, type and content of aggregates, the water to binder ratio, and the volume of the cement ${ }^{41}$. The E-moduli of fiber-reinforced concretes may decrease or increase depending on the orientation or distribution of the fibers in the concrete. This is because the concrete can be assumed to be a highly heterogeneous material due to its composite structure. As the orientations and distributions of the fibers in the concrete mixture are random, the fiber-reinforced concrete is considered more heterogeneous than the plain concrete. Therefore, the E-moduli of sepiolite-fiber-reinforced concretes under compression have very similar changes depending on the distribution of sepiolite in concrete. The principal role of sepiolite fibers is resisting the formation and growth of cracks by providing pinching forces at the crack tips.

\subsubsection{Freezing-thawing test}

An expedited freeze-thaw test consisting of 30 periods is conducted for the purposes of revealing the durability properties of the sepiolite-fiber-reinforced concretes under freeze-thaw circumstances, under which they may be subject to, and then weight loss, density loss, a variation in water-absorption ratios and compres-

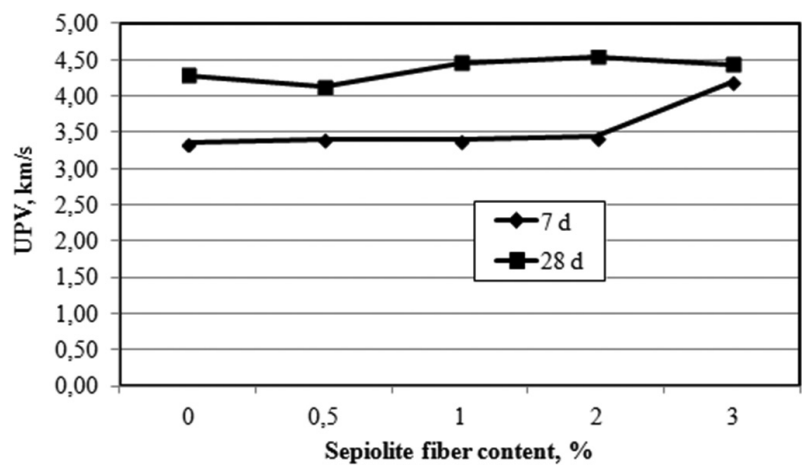

Figure 9: UPV values of sepiolite fiber-reinforced concrete versus fiber content

Slika 9: UPV vrednosti pri betonu ojačenem z vlakni sepiolita $\mathrm{v}$ odvisnosti od vsebnosti vlaken 


\section{S. KOLTKA et al.: THE USE OF NATURAL SEPIOLITE FIBER IN CONCRETE}

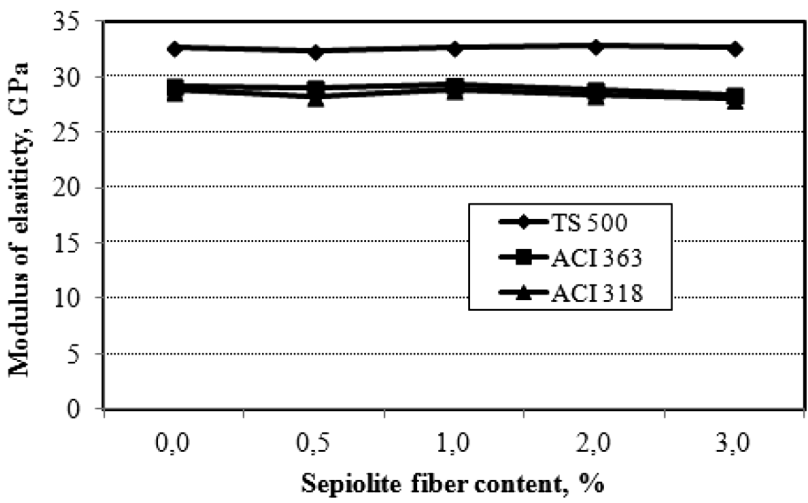

Figure 10: Modulus of elasticity of sepiolite fiber-reinforced concrete Slika 10: Modul elastičnosti betona, ojačanega z vlakni sepiolita

sive strength are determined. In Figure 11, the density loss of $0.5 \%, 1 \%, 2 \%$ and $3 \%$ fiber contents is respectively $1.28 \%, 1.17 \%, 1.15 \%$ and $1.39 \%$, while the density loss of the reference concrete is $1.09 \%$. There is no significant change in the density loss of the white sepiolitic-fiber-reinforced concrete with regards to the reference concrete. Any observations similar to weight loss are conducted in the density of the concretes. However, density loss represents an increase of $7 \%, 6 \%$ and $28 \%$, respectively, upon the addition of $1 \%, 2 \%$ and $3 \%$ fiber. A decrease in weight loss and density loss shows that there is a concrete more resistant against any freeze-thaw effects.

In Figure 12, it is determined that the compressive strength of the $3 \%$ concrete sample obtained from the sepiolite-fiber-reinforced concretes is very close to the reference concrete before and after the freeze-thaw cycle. A maximum difference between the compressive strength values are obtained in the sepiolitic concretes upon the addition of $0.5 \%$ and $1 \%$ fibers with respect to the reference series. Fibers as high as $2 \%$ and $3 \%$ are used in both types of fiber, upon an increase in the strength of the interface of the aggregate-cement paste of the manufactured concretes and also of the cement paste under stresses, the strength losses of the concretes under a freeze-thaw effect are similar to the inspection series.

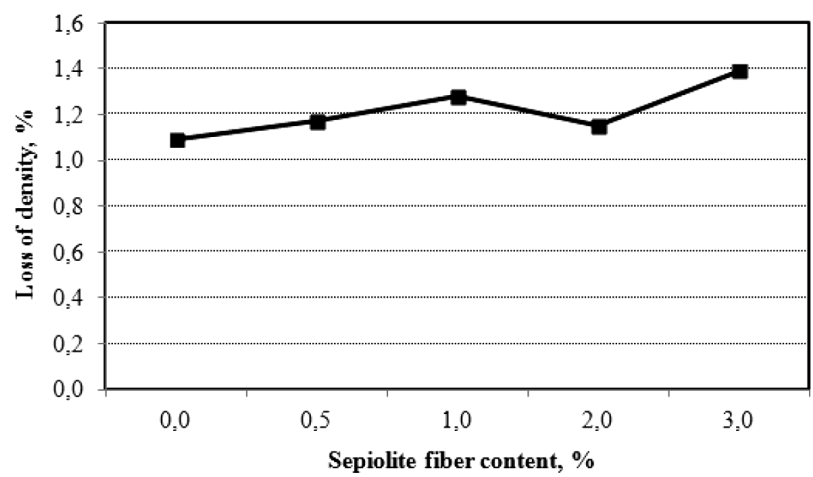

Figure 11: Loss of density of sepiolite reinforced concrete depending on freeze-thaw test

Slika 11: Zmanjšanje gostote betona, ojačanega $\mathrm{z}$ vlakni sepiolita, $\mathrm{v}$ odvisnosti od preizkusa zmrznjeno-odtaljeno

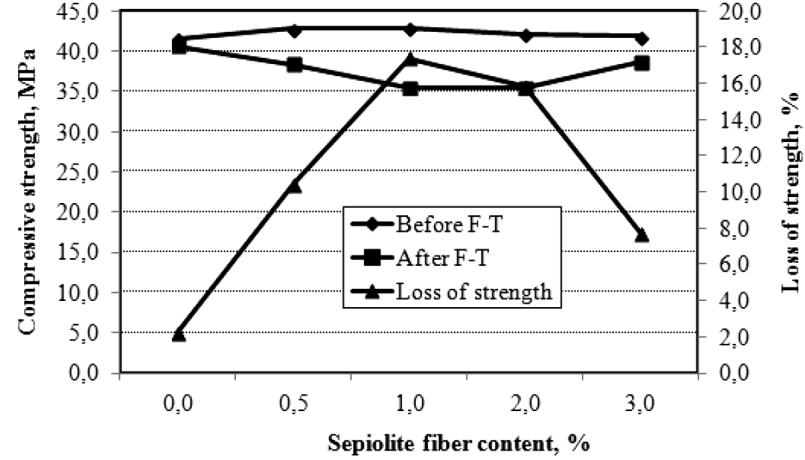

Figure 12: Change of strength of sepiolite reinforced concrete depending on freeze-thaw test

Slika 12: Spreminjanje trdnosti betona, ojačanega z vlakni sepiolita, v odvisnosti od preizkusa zmrznjeno-odtaljeno

In the inspection series, the strength loss is $2 \%$. In the concrete series containing SEPRC, in which $2 \%$ and $3 \%$ fibers are used, the strength losses are determined as $8 \%$ and $5 \%$. Internal stresses occur as a result of the water in the concrete subject to freeze-thaw. Therefore, any cracks tend to occur previously in the cement paste. The sepiolitic fibers make it possible to overcome such internal stresses caused by the frozen water and prevent the concrete from being cracked. Since short fiber types greatly increase the number of fibers used in the concrete, they are used to decrease cracking and increase durability depending on the properties of the materials used; whereas, long fibers aim more often to increase the mechanical properties of the concrete. ${ }^{47}$

Upon use of the white fibers at $0.5 \%, 1 \%$ and $3 \%$, a reduction of $3 \%$ occurs in the $2 \%$ fiber content, increases of $3 \%, 97 \%$ and $44 \%$ are observed with regard to the reference concrete (Figure 12). As a result of such a freeze-thaw procedure, it is shown that dispersion in the white sepiolitic fiber-reinforced concrete is more. In Figure 13, water absorption values are $0.69 \%, 2.33 \%$, $1.23 \%$ and $0.97 \%$, respectively, in $0.5 \%, 1 \%, 2 \%$ and $3 \%$ fiber contents, while the water absorption value of the reference concrete is $0.63 \%$ after the freeze-thaw cycle. Porous structural materials such as concrete have a capability to absorb water as much as open and semi-

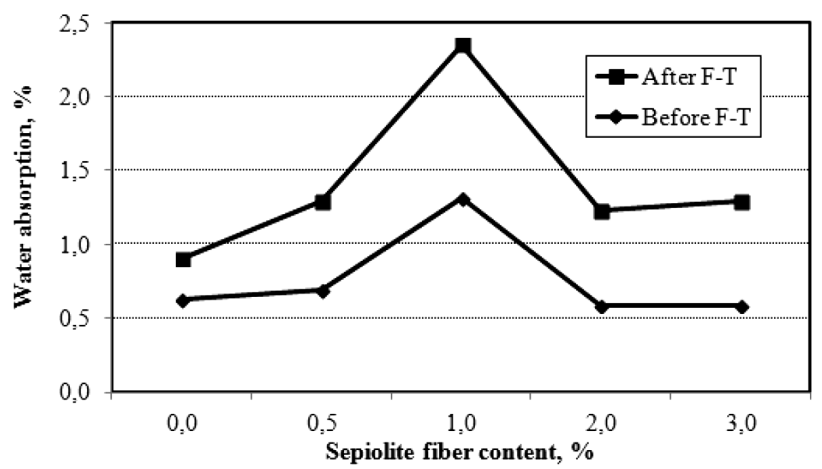

Figure 13: Change of water absorption of sepiolite reinforced concrete depending on freeze-thaw test

Slika 13: Spreminjanje absorpcije vode $\mathrm{v}$ betonu, ojačanem z vlakni sepiolita, v odvisnosti od preizkusa zmrznjeno-odtaljeno 
open gaps included in them. If the gap diameter increases after the internal stress caused by concrete around the frozen water in its gaps before and after freeze-thaw cycle, their water absorption capability increases accordingly. Thus, since mixture and molding of the concretes become difficult upon use of fiber content over $1 \%$, they contain gaps more according to other fiber ratios and consequently the free water in gaps freezes and its volume increases in the freeze-thaw cycles, gaps in the concrete increase and cause absorption of more water. $^{48}$ In the concrete series containing SEPRC, it is observed that there is a smaller increase than the others with respect to water absorption in the inspection and $0.5 \%$ fiber contents.

\section{CONCLUSIONS}

In the manufacture of sepiolite fiber-reinforced concrete, fiber is added to the concrete at $0.5 \%, 1 \%, 2 \%$ and $3 \%$ by weight of the cement added by fiber. In the concrete tests, it is ensured that, upon settlement of the fresh concrete, the sepiolite fibers increase the workability of the concrete and more settlement is obtained. Furthermore, although the white sepiolitic fibers trap more air in the concrete, such an amount is within an acceptable limit (approximately $0.5 \%$ ). The sepiolitic fibers have no effect unit weight of the concrete in fresh state. In the hardened concrete tests, it is determined that the white sepiolitic fibers reduce the compressive strength in comparison to the reference concrete. But, upon addition of the white sepiolitic fibers at $1 \%$ and $3 \%$ to the concrete, the compressive strength gives a value similar to 28-day reference concretes. The bending strength of the white sepiolitic fibers added at $2 \%$ is fairly close of the bending strength of 28-day reference concretes. However, the bending strength reduces at content ratios of $0.5 \%, 1 \%$ and $3 \%$.

In the white sepiolitic fibers, all the content ratios increase the splitting strength. In particular, the splitting strength in the $3 \%$ white sepiolitic fiber content increases by $29 \%$, and as a result of that the interface of the aggregate and cement paste becomes more stable.

The 28-day concretes manufactured with the white sepiolitic fiber according to the ultrasonic pulse velocities are located in a high-quality concrete grade. From SEM studies, it was observed that the white sepiolite fibers are dispersed homogeneously and reinforce especially the interface of the aggregate and cement paste.

In general, it was seen that the sepiolitic fibers have an effect on the fresh concrete. However, it was determined that a $2 \%$ white sepiolitic fiber content gives more positive effects on the tensile strength among the concrete characteristics. Although any chemical additives are used in the concrete upon the addition of $3 \%$ fiber, it is suggested that concrete is used up to $2 \%$ complete with such chemical additives due to difficulties in the mixture.

\section{Acknowledgement}

The investigation was funded by the R\&D Support Program (SAN-TEZ) of Ministry of Science, Industry and Technology with the project number 00523.STZ.2010-1, Republic of Turkey. The authors are grateful for the financial support provided by SAN-TEZ.

\section{REFERENCES}

${ }^{1}$ ACI 544.1R-96, State of The-Art Report on Fiber Reinforced Concrete, 66 (2002)

${ }^{2}$ N. Banthia, N. Nandakumar, Crack growth resistance of hybrid fiber reinforced cement composites, Cement Concrete Comp., 25 (2003), 3-9

${ }^{3}$ A. Yan, K. Wu, X. Zhang, A quantitative study on the surface crack pattern of concrete with high content of steel fiber, Cement and Concrete Research, 3 (2002) 2, 1371-1375

${ }^{4}$ A. S. Ezeldin, P. N. Balaguru, Normal and high-strength fiber-reinforced concrete under compression, Mat. Civil Eng., 4 (1992), 415-427

${ }^{5}$ S. P. Shah, B. V. Rangan, Fibre reinforced concrete properties, ACI J. 68 (1971), 126-135

${ }^{6}$ T. Kavas, E. Sabah, M. S. Çelik, Structural properties of sepiolite-reinforced cement composite, Cement and Concrete Research, 34 (2004), 2135-39

${ }^{7}$ E. M. Bezerra, A. P. Joaquim, H. Savastano Jr, V. M. John, V. Agopyan, The effect of different mineral additions and synthetic fiber contents on properties of cement based composites, Cement Concrete Comp., 28 (2006), 555-563

${ }^{8}$ R. D. T. Filho, K. Joseph, K. Ghavami, G. L. England, The use of sisal fibre as reinforcement in cement based composites, Rev. Bras. Eng. Agríc Ambient, 3 (1999), 245-256

${ }^{9}$ J. M. L. Reis, Fracture and flexural characterization of natural fiber-reinforced polymer concrete, Construction Building Materials, 20 (2006), 673-678

${ }^{10}$ F. O. Slate, Coconut fibers in concrete, Eng. J. Singapore, 3 (1976), 51-54

${ }^{11}$ Z. Li, L. Wang, X. Wang, Cement composites reinforced with surface modified coir fibers, J. Compos. Mater., 41 (2007), 1445-1457

${ }^{12}$ R. Siddique, Properties of concrete incorporating high volumes of class F fly ash and san fibers, Cement and Concrete Research, 34 (2004), 37-42

${ }^{13}$ S. K. Al-Oraimi, A. C. Seibi, Mechanical characterisation and impact behaviour of concrete reinforced with natural fibres, Compos Struct, 32 (1995), 165-171

${ }^{14}$ K. Brauner, A. Preisinger, Struktur und Entstehung des Sepioliths, Tschermaks Miner Petrogr. Mitt., 6 (1956), 120-140

${ }^{15}$ M. Shirvani, H. Shariatmadari, M. Kalbasi, F. Nourbakhsh, B. Najafi, Sorption of cadmium on palygorskite, sepiolite and calcite; Equilibria and organic ligand affected kinetics, Colloid Surf A. 287 (2006), 182-190

${ }^{16}$ A. Alvarez, Sepiolite: properties and uses. Palygorskite-Sepiolite: Occurrences, Genesis and Uses, ed. A. Singer and E. Galan, Amsterdam, (1984) 253-287, Elsevier

${ }^{17}$ B. F. Jones, E. Galan, Hydrous phyllosilicates (exclusive of micas). Sepiolite and Palygorskite, Reviews in Mineralogy, ed. S.W. Bailey, Mineralogical Society of America, 19 (1988), 631-667

${ }^{18}$ H. Arik, S. Kadir, S. Saritaş, Investigation of the structural transformation and refractory properties of the brown sepiolite due to the heating at various temperatures, Turk. J. Eng. Environ. Sci. 20 (1996), 233-244

${ }^{19}$ EN 197-1, Cement - Part 1: Composition, specifications and conformity criteria for common cements, 2011 


\section{MATERIALI IN TEHNOLOGIJE/MATERIALS AND TECHNOLOGY (1967-2017) - 50 LET/50 YEARS}

\section{S. KOLTKA et al.: THE USE OF NATURAL SEPIOLITE FIBER IN CONCRETE}

${ }^{20}$ EN 206-1, Concrete - Part 1: Specification, performance, production and conformity, 2000

${ }^{21}$ EN 12350-6, Testing fresh concrete - Part 6: Density, 2009

${ }^{22}$ EN 12350-7, Testing fresh concrete - Part 7: Air content - Pressure methods, 2009

${ }^{23}$ EN 12390-3, Testing hardened concrete - Part 3: Compressive strength of test specimens, 2009

${ }^{24}$ EN 12390-6, Testing hardened concrete - Part 6: Tensile splitting strength of test specimens, 2009

${ }^{25}$ EN 12390-5, Testing hardened concrete - Part 5: Flexural strength of test specimens, 2009

${ }^{26}$ EN 13791, Assessment of in-situ compressive strength in structures and precast concrete components, 2007

${ }^{27} \mathrm{EN} \mathrm{1367-1,} \mathrm{Tests} \mathrm{for} \mathrm{thermal} \mathrm{and} \mathrm{weathering} \mathrm{properties} \mathrm{of} \mathrm{aggre-}$ gates - Part 1: Determination of resistance to freezing and thawing, 2007

${ }^{28}$ ASTM C 666, Standard test method for resistance of concrete to rapid freezing and thawing, American Society for Testing and Materials, 1997

${ }^{29}$ F. Wang, J. Liang, Q. Tang, J. Meng, Z. Wu, G. Li, Microstructure of sepiolite and its adsorbing properties to dodecanol, Trans Nonferrous Metal Soc. Ch. 16 (2006), 406-410

${ }^{30}$ R. Jarabo, E. Fuente, A. Moral, Á. Blanco, L. Izquierdo, C. Negro, Effect of sepiolite on the flocculation of suspensions of fibre-reinforced cement, Cement and Concrete Research, 40 (2010), 1524-30

${ }^{31}$ B. Chen, J. Liu, Contribution of hybrid fibers on the properties of the high-strength lightweight concrete having good workability, Cement Concrete Res. 35 (2005), 913-917

${ }^{32}$ M. Hsiea, C. Tu, P. S. Song, Mechanical properties of polypropylene hybrid fiber-reinforced concrete, Mat Sci Eng A. 494 (2008), 153-157

${ }^{33}$ J. Edgington, D. J. Hannant, R. I. T. Williams, Steel fiber reinforced concrete, Building Research Establishment. 17 (1974), 64-69

${ }^{34}$ M. Ali, A. Liu, H. Sou, N. Chouw, Mechanical and dynamic properties of coconut fibre reinforced concrete, Construction Building Materials, 3 (2012) 0, 814-825
${ }^{35}$ M. Emiroğlu, Investigation of sepiolite's effects to the mortar and concrete properties, Master's Thesis, Osmangazi University Institute of Science, Eskişehir, 2008

${ }^{36} \mathrm{C}$. Yalçinkaya, An Investigation on the mechanical, durability and microstructure properties of fiber reinforced self-compacting concrete with mineral powders, Master's thesis, Dokuz Eylül University, Institute of Science, İzmir, 2009

${ }^{37}$ S. Kakooei, H.M. Akil, M. Jamshidi, J. Rouhi, The effects of polypropylene fibers on the properties of reinforced concrete structures, Construction Building Materials, 27 (2012), 73-77

${ }^{38}$ K. Bendjillalia, M. S. Goual, M. Chemrouk, Z. Damene, Study of the reinforcement of limestone mortars by polypropylene fibers waste. Seventh international conference on material science, (2011), Beirut (Lebanon)

${ }^{39} \mathrm{~T}$. Uygunoğlu, Investigation of microstructure and flexural behavior of steel-fiber reinforced concrete, Materials and Structures, 41 (2008), 1441-1449

${ }^{40}$ A. Uğurlu, About aggregate-cement bonds, 2. National crushed stone symposium, Istanbul (Turkey), 2008, 213-228

${ }^{41}$ T.Y. Erdoğan, Concrete, ODTÜ Publisher, 2007, Turkey

${ }^{42}$ T. Uygunoğlu, S. Özgüven, Prediction of Modulus of Elasticity in Steel-Fiber Reinforced Concrete by Composite Modeling El-Cezerî, Journal of Science and Engineering, 1 (2014), 19-28

${ }^{43}$ M. Gul, A. Bashir, J. A. Naqash, Study of Modulus of Elasticity of Steel Fiber Reinforced Concrete, International Journal of Engineering and Advanced Technology (IJEAT), 3 (2014), 304-309

${ }^{44}$ ACI 318.RM-02, Building Code Requirements for Structural Concrete. ACI Committee 318, American Concrete Institute, 2002

${ }^{45}$ ACI 363.R-92, State-of-art-report on high strength concrete. ACI Committee 363, American Concrete Institute, 1997

${ }^{46}$ TS 500, Requirements for design and construction of reinforced concrete structures, Turkish Standard Institute, Ankara, Turkey, 2000

${ }^{47}$ CX. Qian, P. Stroeven, Development of hybrid polypropylene-steel fibre reinforced concrete. Cement and Concrete Research, 30 (2000), 63-69

${ }^{48}$ S. Hamoush, M. Picornell-Darder, T. Abu-Lebdeh, A. Mohamed, Freezing and thawing durability of very high strength concrete. Am. J. Eng. Appl. Sci. 4 (2011), 42-51 